\title{
Problematyka płacenia składek na ubezpieczenia społeczne oraz zdrowotne przez osoby nieaktywne zawodowo
}

\section{The issue of payment of contributions for social insurance and health by inactive persons}

\begin{abstract}
Streszczenie:
Zgodnie z ustawą zasadniczą każdy obywatel ma prawo do ochrony życia i zdrowia. Władze publiczne są odpowiedzialne za regulowanie powyższego prawa. Funkcjonujący system zabezpieczenia społecznego ma zapewnić obywatelom pewien standard bezpieczeństwa socjalnego. Idea ubezpieczeń społecznych oparta jest na wspólnym funduszu. Środki publiczne są gromadzone od wszystkich ubezpieczonych obywateli, a następnie przekazywane na świadczenia zdrowotne. Wysokość oraz katalog przysługujących świadczeń szczegółowo określają ustawy, a podstawowym warunkiem ich uzyskania jest regularne opłacanie składek. Osobom zatrudnionym na podstawie umowy o pracę składki na ubezpieczenia społeczne opłaca pracodawca, natomiast osoby prowadzące własną działalność gospodarczą odprowadzają składki samodzielnie. W związku z powyższym wskazane grupy osób posiadają ogólny dostęp do opieki zdrowotnej. Należy odpowiedzieć sobie na pytanie, co dzieje się z osobami, które nie są lub przestały być aktywne zawodowo? Udzielenie odpowiedzi na powyższe pytanie będzie przedmiotem niniejszego opracowania.
\end{abstract}

Słowa kluczowe: ubezpieczenia społeczne, ubezpieczenia zdrowotne, składki, osoby bezrobotne, osoby nieaktywne zawodowo

\footnotetext{
Abstract:

Pursuant to the Constitution, every citizen has the right to have their life and health protected. Public authorities are responsible for regulating this right. The binding so-
} 
Anna Kłudkowska - Problematyka płacenia składek...

cial security system is designed to provide citizens with a respective standard of social security. The social security concept is based upon a common fund. Public funds are collected from all insured citizens, and then transferred to cover the medical services. The quantity and the range of benefits are set out in detail by laws, and the precondition to obtain such benefits is regular payment of contributions. In case of people employed on the basis of employment contracts, social security contributions are paid by the employer; while self-employed persons pay contributions on their own. Accordingly, these groups of people have general access to the healthcare. A question arises: what happens to people who are not or are no longer professionally active? It is the role of this article to answer the above question.

Keywords: social security; health insurance contributions; the unemployed; professionally inactive persons

\section{Wprowadzenie}

Konstytucja Rzeczypospolitej Polskiej gwarantuje wszystkim obywatelom Polski dostęp do publicznej opieki zdrowotnej. Wynika to z brzmienia art. 68 ust. 1 i 2 :

1. Każdy ma prawo do ochrony zdrowia.

2. Obywatelom, niezależnie od ich sytuacji materialnej, władze publiczne zapewniają równy dostęp do świadczeń opieki zdrowotnej finansowanej ze środków publicznych. Warunki i zakres udzielania świadczeń określa ustawa.

Zgodnie z powyższym Konstytucja RP zapewnia prawo do ochrony zdrowia zarówno ubezpieczonym, jak i nieubezpieczonym obywatelom. Przepisy wynikają wprost z prawa do ochrony zdrowia, z prawa do godności każdego człowieka oraz z prawnej ochrony życia. Podkreśla również, że zakres korzystania z powyższego prawa nie jest zależny od sytuacji materialnej danej osoby. Władze publiczne są odpowiedzialne za regulowanie tego prawa, przy czym mają za zadanie stworzyć takie instytucje, które umożliwią zapobieganie oraz zwalczanie chorób oraz swobodny dostęp do leczenia. Środki publiczne są gromadzone od wszystkich ubezpieczonych obywateli i przeznaczone na świadczenia zdrowotne. W przypadku osób nieubezpieczonych środki zdrowotne również są przekazywane w razie wystąpienia nie- 
bezpieczeństwa zagrażającego zdrowiu i życiu. Należy nadmienić, że równy dostęp nie oznacza całkowitej bezpłatności świadczeń. Ograniczenia są regulowane przez odrębne przepisy ustawy, znaczącą rolę odgrywa również ekonomiczna sytuacja państwa.

Zakład Ubezpieczeń Społecznych ma za zadanie zapewnić wszystkim obywatelom opiekę ubezpieczeniową. Zgodnie z powyższym nie występuje żaden podział lub dyskryminacja członków społeczeństwa państwa polskiego. W zamian za korzystanie z publicznej służby zdrowia jest odprowadzona składka. Wysokość składki zależy od przychodu pracownika z tytułu zatrudnienia ${ }^{1}$. Osoby prowadzące własną działalność gospodarczą opłacają składki samodzielnie, natomiast w przypadku osób zatrudnionych w oparciu umowy o pracę składki odprowadza pracodawca. W związku z powyższym wskazane osoby posiadają ogólny dostęp do opieki zdrowotnej ze względu na status zatrudnienia związany z pracą zawodową ${ }^{2}$. Jednakże trzeba zadać sobie pytanie, jak wygląda wówczas sytuacja osób, które nie są lub przestały być aktywne zawodowo? Czy rzeczywiście zgodnie z zapisami art. 68 ust. 2 w Konstytucji RP odnośnie materialnej sytuacji obywateli władze publiczne zapewniają równy dostęp do świadczeń opieki zdrowotnej finansowanej ze środków publicznych? Kto staje się płatnikiem w sytuacji, gdy ustanie stosunek pracy? W jaki sposób Zakład Ubezpieczeń Społecznych zapewnia opiekę ubezpieczeniową oraz jakie są ku temu przesłanki? Udzielenie odpowiedzi na powyższe pytania będą przedmiotem dalszej części niniejszego opracowania. Warto się bliżej przyjrzeć temu problemowi, gdyż tematyka osób nieaktywnych zawodowo wzbudza wiele niejasności w sektorze ubezpieczeń społecznych.

${ }^{1}$ Rozporządzenie Ministra Pracy i Polityki Społecznej z dnia 18 grudnia 1998 r. w sprawie szczegółowych zasad ustalania podstawy wymiaru składki na ubezpieczenie emerytalne i rentowe. (t. j. Dz. U. 2015, poz. 2236 ze zm.).

2 M. Jasińska, Składki ZUS a osoby bezrobotne, http://www.mojportalfinansowy.pl /artykul/bezrobotni-a-zus/ [dostęp: 10-01-2017]. 
Anna Kłudkowska - Problematyka płacenia składek...

\section{Ogólna charakterystyka ubezpieczeń społecznych}

Ubezpieczenia społeczne są oparte na wspólnym funduszu. Rozpatrywane są systemowo, ponieważ stanowią strukturę zagwarantowanych ustawowo świadczeń związanych z pracą. Charakter ubezpieczeń społecznych jest roszczeniowy. Głównym ich celem jest pokrycie potrzeb obywateli wywołanych przez zdarzenia losowe lub inne zdarzenia zrównane z nimi. Roszczenia te są realizowane przez instytucje do tego powołane, jedną z nich stanowi Zakład Ubezpieczeń Społecznych. Finansowanie ubezpieczeń społecznych podlega zasadzie bezpośredniego lub pośredniego rozłożenia ciężaru powyższych świadczeń ${ }^{3}$.

Reasumując, podstawowym celem ubezpieczeń społecznych jest zapewnienie bezpieczeństwa socjalnego wszystkim tym osobom, które z powodu zajścia określonych przez prawo zdarzeń losowych (można tu wymienić: chorobę, kalectwo, ciążę, starość) nie mogą utrzymać się z własnej pracy. Zwraca się uwagę, iż wypłaty świadczeń mogą mieć charakter długoterminowy, krótkoterminowy bądź dożywotni. Ubezpieczenia społeczne stanowią instrument polityki socjalnej każdego państwa, niosą pomoc społeczną oraz pewnego rodzaju zaopatrzenie dla osób potrzebujących.

\subsection{Rodzaje ubezpieczeń społecznych}

Zgodnie z art. 1 ustawy o systemie ubezpieczeń społecznych na ubezpieczenia społeczne składają się:

a) ubezpieczenia emerytalne,

b) ubezpieczenia rentowe,

c) ubezpieczenia chorobowe,

d) ubezpieczenia wypadkowe.

Zgodnie z powyższym wymienia się cztery podfundusze w ramach Funduszu Ubezpieczeń Społecznych (FUS), którego dysponentem jest

3 W. Szubert, Ubezpieczenia Społeczne. Zarys Systemu, Warszawa 1987, s. 66. 
Zakład Ubezpieczeń Społecznych ${ }^{4}$. W przypadku zaistnienia poszczególnych zdarzeń losowych wypłacane są określone świadczenia ze zgromadzonych wskazanych na funduszach środków.

Wymienia się cztery podfundusze, a mianowicie: chorobowy, rentowy, wypadkowy i emerytalny. Z funduszu chorobowego wypłacane są świadczenia w przypadku choroby oraz macierzyństwa - czyli przejściowego aspektu niewykonalności pracy. Fundusz rentowy stanowi zabezpieczenie na wypadek inwalidztwa i śmierci żywiciela, co ma równoznaczny związek z całkowitą niezdolnością do pracy. Fundusz wypadkowy gromadzony jest w celu ochrony ryzyka wypadku przy pracy. Ostatni wskazuje się fundusz emerytalny, jako zabezpieczający ryzyko starości. Przy powyższych podfunduszach funkcjonują ponadto fundusze rezerwowe ${ }^{5}$.

\section{Zasady finansowania składek za ubezpieczenia społeczne przez płatników}

Zarówno w ubezpieczeniu społecznym jak i zdrowotnym znaczącą rolę odgrywa pozycja płatnika składek. Stanowi on główny element systemu zabezpieczenia społecznego. Trudno jest jednoznacznie podać definicję płatnika składek, zarówno na poziomie ubezpieczeń społecznych jak i świadczeń zdrowotnych. Ten problem został szczegółowo opisany w ustawie z dnia 13 października 1998 r. o systemie ubezpieczeń społecznych w art. 4 pkt 2 lit. a-za ${ }^{6}$. We wspomnianym przepisie wylicza się wszystkie podmioty będące płatnikami składek.

Analizując przedstawioną (powyżej) regulację prawną można ogólnie zdefiniować płatnika składek. Płatnikiem staje się każda osoba lub podmiot, która deklaruje się opłacać składki za ubezpieczenie. Powyższe zobowiązanie jest regulowane odpowiednimi przepisami. Pobie-

\footnotetext{
4 T. Szumlicz, Ubezpieczenia społeczne. Teoria dla praktyki, Bydgoszcz-Warszawa 2005, s. 235.

5 Ibidem, s. 218.

6 D. Karkowska, A. Nerka, Pozycja płatnika składek w ubezpieczeniu społecznym i zdrowotnym, Warszawa 2007, s. 15.
} 
Anna Kłudkowska - Problematyka płacenia składek...

rana składka przekazywana jest następnie do Zakładu Ubezpieczeń Społecznych. Wczytując się w artykuł prawny, dowiadujemy się, że nie tylko płatnik odprowadza składki za siebie, ale również robi to za innych ubezpieczonych z jakiegokolwiek tytułu. W związku z powyższym może to być osoba, która $\mathrm{z}$ własnej woli zobowiązuje się do płacenia składek, ale również mogą to być osoby prowadzące działalność pozarolniczą. W niektórych przypadkach jako płatników składek wskazuje się instytucje, np. w stosunku do osób pobierających zasiłek dla bezrobotnych lub stypendium wspomnianym płatnikiem staje się powiatowy urząd pracy. Podobna sytuacja wygląda u osób, które rezygnują z zatrudnienia z konieczności sprawowania bezpośredniej opieki nad długotrwale lub ciężko chorym członkiem rodziny, pobierają one wówczas zasiłek pielęgnacyjny. W powyższym przypadku płatnikiem składek staje się ośrodek pomocy społecznej. W przypadku osób przebywających na urlopie macierzyńskim i w związku z pobieranym zasiłkiem płatnikiem odprowadzającym składki staje się ZUS.

Odnosząc się do ustawy o systemie ubezpieczeń społecznych, trudno jednoznacznie zdefiniować pojęcie płatnika. Powyższa próba takiej definicji jest zbyt ogólna, ponieważ występują od niej liczne wyjątki.

\subsection{Obowiązki płatnika}

Do podstawowych obowiązków płatnika składek należy między innymi rozstrzyganie obowiązku ubezpieczeń społecznych, jak również informowanie o ustaniu tytułu do ubezpieczeń społecznych. Ważne jest zarówno obliczanie dochodów jak i ich potrącanie ubezpieczonych na poczet odprowadzania składek do FUS. W toku tej procedury ważne jest ustalenie prawa do świadczeń oraz sprawdzenie ich wysokości. Istotne jest również dokonywanie systematycznej wypłaty. Płatnik składek zobowiązuje się składać miesięcznie imienne raporty oraz 
imienne raporty korygujące. $\mathrm{W}$ trakcie rozliczeń dosyłane są deklaracje rozliczeniowe oraz deklaracje rozliczeniowe korygujące ${ }^{7}$.

Płatnicy składek muszą zgłosić do zakładu ubezpieczeń wszystkich swoich pracowników oraz pozostałe osoby obowiązkowo objęte ubezpieczeniem społecznym. Wyjątek od powyższego stanowią prokuratorzy. Zgłoszenia do ubezpieczeń społecznych i do ubezpieczeń zdrowotnych dokonuje się w ciągu 7 dni od daty powstania obowiązku ubezpieczeń. Osoby chcące dobrowolnie się ubezpieczyć i jednoznacznie objęte ubezpieczeniem społecznym na zasadzie dobrowolności składają wniosek $\mathrm{z}$ wybranymi ryzykami ubezpieczeń $\mathrm{w}$ terminie przez siebie wskazanym. Inaczej wygląda sytuacja w przypadku kontynuacji ubezpieczenia emerytalnego bądź rentowego - wskazuje się termin 30-dniowy od ustania ubezpieczeń społecznych. W przypadku rezygnacji ze składek z ubezpieczeń społecznych płatnik jest zobowiązany w terminie 7 dni złożyć stosowny wniosek w jednostce organizacyjnej ZUS8.

Płatnik nie tylko przekazuje składki na ubezpieczenia społeczne jest również obciążony dodatkowo terminowym obowiązkiem opłacenia składek na ubezpieczenia zdrowotne, na Fundusz Pracy i Fundusz Gwarantowanych Świadczeń Pracowniczych. Składki opłacane są w formie bezgotówkowej, z tytułu obciążenia rachunku bankowego płatnika składek.

W przypadku nieopłacenia terminowo składek przez płatnika, zarówno na ubezpieczenia zdrowotne jak i ubezpieczenia społeczne, Fundusz Pracy oraz Fundusz Gwarantowanych Świadczeń Pracowniczych nalicza odsetki za zwłokę określone w ustawie9.

Zakład Ubezpieczeń Społecznych udostępnia wszystkie informacje związane z ubezpieczeniem oraz ze świadczeniami swoim płatnikom. Wgląd do danych płatnik otrzymuje poprzez zalogowanie się do swo-

${ }^{7}$ S. Pieńkowska-Kameniecka, Ubezpieczenia społeczne jako metoda zabezpieczenia społecznego, [w:] E. Kucka (red.), Ubezpieczenia Społeczne i Gospodarcze, Olsztyn 2009 , s. 366.

8 Ibidem, s. 367.

9 Ustawa z dnia 29 sierpnia1997 r. Ordynacja podatkowa (t. j. Dz. U. 2017, poz. 201). 
Anna Kłudkowska - Problematyka płacenia składek...

jego konta. W systemie znajdziemy również informacje o obowiązkowych składkach i wpłatach.

\section{Osoby nieaktywne zawodowo, które uzyskały status osoby bezrobotnej}

Bezrobotni podlegają obowiązkowi ubezpieczenia zdrowotnego pod warunkiem spełnienia podstawowej przesłanki, a mianowicie że nie są objęci ubezpieczeniem z tzw. innego tytułu (np. z powodu podjęcia zatrudnienia, pracy na podstawie umowy zlecenia, zgłoszenia do ubezpieczenia przez małżonka) ${ }^{10}$. Należy nadmienić, iż prawo do świadczeń opieki zdrowotnej przez osoby bezrobotne trwa przez następne 30 dni po przerwaniu stosunku pracy, czyli od dnia uzyskania przez nią statusu bezrobotnego. Po upływie tego terminu prawo to ustaje.

Osoba bezrobotna, aby mogła zostać objęta ubezpieczeniem, może zarejestrować się we właściwym Urzędzie Pracy ze względu na swoje stałe bądź czasowe zameldowanie. W przypadku nieposiadania żadnego zameldowania osoba bezrobotna może zgłosić się do urzędu pracy w miejscu, w którym aktualnie przebywa. Powinna wówczas złożyć stosowne oświadczenie zawierające informację, że nie jest zarejestrowana w żadnym innym urzędzie pracy. Następnie w wyznaczonych terminach powinna się stawiać do urzędu pracy. Obecność ta ma istotny wpływ na uzyskanie bądź podtrzymanie statutu osoby bezrobotnej, ponieważ brak stawienia się do urzędu pracy może jednoznacznie wiązać się z utratą statusu osoby bezrobotnej, co za tym idzie - utratą ubezpieczenia społecznego.

Rejestracja w urzędzie pracy powoduje, że osoba nieaktywna zawodowo z chwilą uzyskania statusu bezrobotnego zostaje objęta ubezpieczeniem zdrowotnym, a także zostaje zgłoszona do systemu

10 Ubezpieczenie zdrowotne bezrobotnego, http://www.infor.pl/prawo/bezrobotny/ status-bezrobotnego/279592,Ubezpieczenie-zdrowotne-bezrobotnego.html [dostęp: 10-01-2017 r.]. 
eWUŚ - czyli do Elektronicznej Weryfikacji Uprawnień Świadczeniobiorców.

Składkę zdrowotną za osobę zarejestrowaną, która posiada status osoby bezrobotnej, opłaca właściwy urząd pracy z zebranych środków z Funduszu Pracy ${ }^{11}$. Ten warunek jest spełniony wówczas, gdy nie ma innej podstawy do objęcia osoby bezrobotnej obowiązkiem ubezpieczenia (tzn. jeżeli nie podlega obowiązkowi ubezpieczenia zdrowotnego $\mathrm{z}$ innego tytułu, np. pobierania renty rodzinnej, ubezpieczenia w KRUS). Podstawą wymiaru składek emerytalnych oraz rentowych jest kwota zasiłku doliczana z kosztami uzyskania i kwotą podatku dochodowego. Powyższe sprawia, iż wciąż zachowuje się ciągłość ubezpieczeniowa ${ }^{12}$. Jest to istotne dla przyszłościowego rozporządzenia świadczeń emerytalnych, gdyż czas pobierania zasiłków zostaje wliczony do okresów składkowych przez Zakład Ubezpieczeń Społecznych. To również sprawia, że luka czasowa w dostarczaniu składek do filaru OFE nie występuje.

Reasumując, osoby, które utraciły status osób aktywnych zawodowo, jeszcze przez 30 dni od ustania stosunku pracy mogą korzystać ze świadczeń opieki zdrowotnej. Następnie, aby mieć ciągłość i prawo do powyższych świadczeń, powinny zarejestrować się $\mathrm{w}$ urzędzie pracy odpowiednim ze względu na swoje dotychczasowe zamieszkanie bądź zameldowanie. Składki za osoby bezrobotne są opłacane przez urząd pracy ze wspólnego Funduszu Pracy.

\section{Osoby nieaktywne zawodowo a obowiązkowe ubezpieczenia społeczne}

Przepisy uszczegóławiają, które osoby nie będące w stosunku pracy zawodowej obejmuje obowiązkowe ubezpieczenie emerytalne oraz rentowe. Pomijając osoby z prawem do zasiłku, ubezpieczeniem są

\footnotetext{
11 Art. 85 ust. 6 Ustawy z dnia 27 sierpnia 2004 r. o świadczeniach opieki zdrowotnej finansowanych ze środków publicznych (t. j. Dz. U. 2016, poz. 1793 ze zm.).

12 M. Jasińska, Składki ZUS a osoby bezrobotne, http://www.mojportalfinansowy. $\mathrm{pl} /$ artykul/bezrobotni-a-zus/ [dostęp: 10-01-2017 r.].
} 
Anna Kłudkowska - Problematyka płacenia składek...

objęte również osoby nieaktywne zawodowo, które pobierają stypendium w czasie pełnienia stażu lub szkoleń w okresie przygotowania zawodowego. Ponadto osoby pobierające stypendium są objęte również ubezpieczeniem wypadkowym.

Wskazuje się, iż stażystą może zostać osoba bezrobotna, która nie ukończyła 25 roku życia - do tej grupy wiekowej należą w głównej mierze absolwenci zarówno szkół gimnazjalnych, jak i ponadgimnazjalnych. W przypadku absolwentów szkół wyższych stażystą może zostać osoba do ukończenia 27 roku życia, jednakże nie dłużej niż przez 12 miesięcy od zdobycia dokumentu poświadczającego ukończenie nauki. Zwracamy uwagę, iż absolwenci szkół wyższych są objęci ubezpieczeniem zdrowotnym jedynie jeszcze przez 4 miesiące od momentu ukończenia studiów, obrony pracy dyplomowej lub skreślenia z listy studentów. Jeżeli absolwenci szkół wyższych nie będą podlegać ubezpieczeniu z innego tytułu, mogą zgłosić się do Powiatowego Urzędu Pracy bądź wykupić dobrowolne ubezpieczenie, zawierając tym samym umowę z Narodowym Funduszem Zdrowia. Podobnie sytuacja wygląda u osób, które założyły działalność gospodarczą i zdecydowały się ją zawiesić. Z chwilą zarejestrowania się w urzędzie pracy również powyższe osoby podlegają ubezpieczeniu zdrowotnemu.

\section{Podsumowanie}

Sama idea ubezpieczeń społecznych oparta jest na gromadzeniu wspólnego funduszu. W razie wystąpienia nagłego, nieprzewidzianego zdarzenia losowego świadczenia są wypłacane obywatelom w celu pokrycia ich podstawowych potrzeb. Ubezpieczenia społeczne mają charakter roszczeniowy, rozpatrywane są systemowo, ponieważ stanowią strukturę zagwarantowanych ustawowo świadczeń związanych z pracą. Płatnikiem staje się każda osoba lub podmiot, które deklarują się opłacać składki za ubezpieczenie. Zobowiązanie to jest regulowane odrębnymi przepisami. Pobierana składka przekazywana jest do Za- 
kładu Ubezpieczeń Społecznych. Płatnik odprowadza składki za siebie, ale również za innych ubezpieczonych z jakiegokolwiek tytułu.

Osoba, która utraciła zatrudnienie, aby mogła zostać objęta ubezpieczeniem, musi zarejestrować się $\mathrm{w}$ urzędzie pracy właściwym ze względu na swoje stałe bądź czasowe zameldowanie. Rejestracja w urzędzie pracy powoduje, że osoba nieaktywna zawodowo z chwilą uzyskania statusu bezrobotnego zostaje objęta ubezpieczeniem zdrowotnym. Składkę zdrowotną za osobę zarejestrowaną, która posiada status osoby bezrobotnej, opłaca właściwy urząd pracy. Osoba ta powinna w wyznaczonych terminach stawiać się do urzędu pracy. Obecność ta ma znaczący wpływ na uzyskanie statusu osoby bezrobotnej, gdyż brak stawienia się do urzędu pracy może wiązać się z utratą statusu osoby bezrobotnej, a co za tym idzie - z utratą ubezpieczenia społecznego.

\section{Bibliografia:}

\section{Pozycje zwarte i artykuły:}

Karkowska D., Nerka A., Pozycja płatnika składek w ubezpieczeniu społecznym i zdrowotnym, Wyd. Wolters Kluwer, Warszawa 2007.

Pieńkowska-Kameniecka S., Ubezpieczenia społeczne jako metoda zabezpieczenia społecznego, [w:] E. Kucka (red.), Ubezpieczenia Społeczne i Gospodarcze, Wyd. UWM, Olsztyn 2009.

Szubert W., Ubezpieczenia Społeczne. Zarys Systemu, Wyd. PWN, Warszawa 1987.

Szumlicz T., Ubezpieczenia społeczne. Teoria dla praktyki, Wyd. Oficyna Wydawnicza Branta, Bydgoszcz-Warszawa 2005.

\section{Akty prawne:}

Dyrektywa o pośrednictwie ubezpieczeniowym z dnia 30 września $2002 r$. Nr 2002/92/WE.

Konstytucja Rzeczypospolitej Polski z dnia 2 kwietnia 1997 r.

Ustawa z dnia 14 grudnia 1994 r. o zatrudnieniu i przeciwdziałaniu bezrobociu (Dz. U. 2003, Nr 58, poz. 514, z późn. zm.). 
Anna Kłudkowska - Problematyka płacenia składek...

Rozporzadzenie Ministra Pracy i Polityki Społecznej z dnia 18 grudnia 1998 r. w sprawie szczegółowych zasad ustalania podstawy wymiaru składki na ubezpieczenie emerytalne i rentowe. (Dz.U. Nr 161, poz. 1106).

Ustawa z dnia 29 sierpnia1997 r. Ordynacja podatkowa (Dz. U. Nr 137, poz. 926 z późn. zm).

Ustawa z dnia 13 października 1998 r. o systemie ubezpieczeń społecznych (Dz. U. 2009, Nr 205, poz. 1585 ze zm.).

Ustawa z dnia 20 kwietnia 2004 r. o promocji zatrudnienia i instytucjach rynku pracy (Dz. U. 2008, Nr 69, poz. 415 ze zm.).

Ustawa z dnia 27 sierpnia 2004 r. o świadczeniach opieki zdrowotnej finansowanych ze środków publicznych (Dz. U. 2008, Nr 164, poz. 1027 ze zm.).

\section{Źródła internetowe:}

M. Jasińska, Składki ZUS a osoby bezrobotne, Warszawa.

http://www.mojportalfinansowy.pl/artykul/bezrobotni-a-zus/ [dostęp: 15-012017].

Ubezpieczenie zdrowotne bezrobotnego, http://www.infor.pl/prawo/bezro botny/status-bezrobotnego/279592,Ubezpieczenie-zdrowotne-bezrobot nego.html [dostęp: 10.01.2017].

http://www.zus.pl/. 